\title{
Digital inclusion in a disadvantaged Swedish suburb - Trust and participation to form Quality of Government
}

\author{
Elin Wihlborg \\ Linköping University \\ Elin.Wihlborg@liu.se
}

\author{
Ahmed Kaharevic \\ Linköping University \\ Ahmed.Kaharevic@liu.se
}

\author{
Aneta Kulanovic \\ Linköping University \\ Aneta.Kulanovic@liu.se
}

\author{
Mattias Elg \\ Linköping University \\ Mattias.elg@liu.se
}

\begin{abstract}
Digital inclusion is the key for a sustainable and inclusive society. In particular, digital governmental services must be impartial, inclusive and available for everyone eligible for the services. Digital inclusion is a key for trust of government in a more digital society. However, the motives access, use and competences to be digital included varies in line with other forms socioeconomic stratification. It is also complicated to reach those who are digital excluded in traditional survey methods. This paper presents a field study on digital inclusion in a disadvantaged Swedish suburb, where we made a structured interview survey to reach groups that are usually hard to survey. The analysis shows that those who find it easy to search on the Internet also experience more inclusion in the Swedish society. In addition, more advanced use as on-line payments and use of eID seems to increase the trust in public authorities. Thereby, digital inclusion can be seen as a factor enhancing even quality of government, that has to be further investigated.
\end{abstract}

\section{Introduction}

Digital inclusion is the key for a sustainable and inclusive society [1], but also for a trustworthy and legitimate digitalization of governments [2]. If not all citizens have access to digital governmental services, competences to find, use information and services or possibilities to participate in digital democracy and the government in a digital era, it cannot be seen as impartial and legitimate. Besides inclusion, impartiality of public services has appeared as the key factor for high quality of government in international studies [3]. According to Rothstein [3], the quality of government, e.g. access to public services, is central for the perceived legitimacy of the state. Putnam [4] evoked a discussion regarding trust in ethnic diverse communities by showing that ethnic diversity hampers trust in general and in relation to public authorities in particular. The academic discourse of quality of government points at the complexity regarding how to conceptualize and measure trust. Adding digitalization to the quality of government raises even new dimensions to take into account for the evaluation of quality of government [2]. Thus, trust in relation to digital government has to be further studied and in particular among groups that could be expected to have lower trust in government.

Disadvantaged suburbs in Sweden are known for being hard-to-survey $[5,6]$. A suburb in Sweden is a disadvantaged area, partly characterized by ethnic diversity, low income and education, opening for risks for social exclusion and less trust in governments. Thus, it is important to focus on social and digital inclusion in these areas to increase knowledge on trust in government as well as in digital governmental services.

Traditional methods such as calling, mailing or online surveys often lead toa low response rate in these areas, and are unsatisfactory approaches when surveying socioeconomic groups as in the suburbs. However, it is not that the inhabitants are hard to survey in essence, the outcome rather depends on the research design and methods used [7, 8]. Thus, we have developed and used a method more suited for surveying Swedish suburbs [5]. Our general question is here addressed through focusing on a specific case a Swedish suburb where we have conducted structured surveyinterviews with 323 people through on-site and in-home interviews.

\subsection{Aim and research questions}

This paper presents a field study survey on digital inclusion in a disadvantaged Swedish suburb and discuss how digital inclusion may affect the quality of government.

The paper is structured around two main research questions that also point at the main contributions of the paper.

How is digital inclusion experienced and described in a disadvantaged suburb? 
- What factors can impact digital inclusion in a Swedish disadvantaged suburb and how does it relate to trust in government?

\subsection{Outline of the paper}

This paper proceeds in six steps by starting with a brief overview of digital inclusion and secondly the theoretical framing of quality of government. Thereafter, the research design is presented both as a more general methodological discussion and as a presentation of the specific case study area. In the fifth section the results from the survey are presented. Finally, we discuss our conclusions and implications from the survey in the suburb regarding both digital inclusion and its implication on the meanings of quality of government.

\section{Digital inclusion a key for democracy and participation}

The main argument framing the survey presented in this paper is that digital exclusion may hamper the trust in government and thereby the quality of government. Thus, two lines of research are briefly reviewed. Firstly, we summarize some key studies on digital inclusion and secondly relating to the models on quality of government, to combine them as a framing for the analysis.

\subsection{Digital inclusion}

A disadvantaged suburban area is characterized of low socioeconomic status, combing low income, weak connections to the labor market, low education and other aspects of vulnerability but also high ethnic diversity. Low socio-economic status is also related to digital exclusion and addressed as a main risk factor for digital exclusion by several researchers [see for example 9, 10, 11]. In contrast to physical and material barriers towards digital inclusion, socio-economic status is a multifaceted factor that affects the extent to which one can benefit from digitalization [9]. The socioeconomic factors that have been addressed in research are mainly age, gender, education, income, occupation, relationship status and disabilities $[12,13]$. Socioeconomic barriers to digital inclusion are difficult to eliminate. There are two main argument for this; firstly, that digital technology continuously develops and new applications and services emerges, and secondly, since a person may be digital included in one area but still excluded in others [14].

Socioeconomic stratification is closely related to ethnicity in most western states $[15,1]$. Using ethnicity as a variable for understanding digital inclusion is more common in research about motivation/attitude and access, than skills and usage [1]. An American study by the Pew Research Center [16] shows a clear variation in the Internet use due to ethnographic background. Similar results are seen in a large study in Brazil with data from 2005-2013. Whites used the Internet to a larger extent than non-White, and they also had a slighter higher access to mobile phones [17]. Research has also shown that smartphones and Internet use are very important for migrants, in order to get oriented in a new environment, to learn the new language and to keep in touch with relatives that can be spread all around the globe. Taken together there are high motivation for migrants to use the Internet, ICT and related technology $[18,19]$. However, in these groups use of the Internet is far from a directly related to use of digital government services in the new home country. For example, extensive use of social media in one's mother tongue may not merge into extensive use of public services in the new home country. Experiences from our previous studies at Swedish public libraries show that some migrants are expert on using social media like the "What's up app", but don't know at all how to use basic public e-services [20]. Thus, it is important to study the use Internet and digital government services in suburbs with high levels of immigrants.

\subsection{Quality of government in a Digital Era}

Quality of government refers to trustworthy, reliable, impartial, uncorrupted, and competent government institutions. The theories on quality of government builds on long time series research and standardized international datasets including samples from several nations. One of the key contributions is that the level of impartiality in governmental services clearly correlates to the quality of the service and in turn also with the citizens' trust towards the government. The Quality of Government (QoG) theory points at the mutual interplay of governments and their citizens. The comparative analyses also show the importance of trustworthy, impartial, and uncorrupted government institutions as a precondition for citizens' willingness to support policies for social insurance [21].

Since legitimacy and trust towards the state earlier mainly had been seen as a consequence of citizens possibilities to influence politics and transparency in decision making, as input legitimacy. The quality of government theory in contrast showed the importance of output, governmental achievements through trustworthy services to the general public for trust and legitimacy [22]. In other words, if citizens consider services provided for them by the state as of high quality, then the trust towards the state will prosper [23]. 
The focus on impartiality in the quality of government theory has also shown that it has an integrative and inclusive effect. A recent study in Sri Lanka [15] shows that policies towards inclusion have a substantial influence on the quality of government, institutional impartiality and citizenship rights of minorities. Thus, quality of government is a particular important approach for policy and practice in disadvantaged communities.

\subsection{Disadvantaged suburbs}

Disadvantaged suburbs are vulnerable areas with high level of criminality and a dissatisfaction with society, a situation rooted in the social context rather than amongst the individual criminal, there are a shortage of housing, employment and other resources in these areas [24]. In Sweden 20\% of the population born outside Europe live in an overcrowded home and in disadvantaged suburbs. Almost $40 \%$ of the youth in vulnerable areas leave elementary school with nonapproved grades, the national average is $13 \%$. There is also often an anxiety amongst ethnic groups because of historical and current global conflicts, which is also enhanced by the online society and access to social media, the Swedish police argues [24].

Segregation in Sweden is portrayed as something that exists in suburbs with low income rather than areas with higher income or society as a whole [25]. There is an increasing polarization in Swedish suburbs with growing inequalities and social tensions [26]. Social inequality and residential segregation have increased in Europe, both regarding level of income inequality and spatial segregation. It often results in a bad circle for low-income groups where moving upwards in the sociospatial mobility becomes more difficult [27]. Trust in ethnic diverse communities is not hampered by the diversity itself but the socioeconomic, ethnical and residential segregation [28].

\subsection{Quality of government in a Digital Era and the challenges of inclusion}

This paper focus on how digital inclusion may affect the quality of government, through a structured interview survey in a disadvantaged suburb. The analytical approach aims to grasp how digitalization affects residents' expressions of the quality of governmental services and thus the quality of government.

We aim to uncover expressions of legitimacy of public services, both digital and in person, and government. This trust in the digital era builds on how the public is expressed in new socio-technical arrangements were actors and agencies search for and frame new structures and practices [2, 29]. Turning services into e-services adds new layers on to how trust and legitimacy towards the government are formed. To maintain quality of government, new e-services have to be developed in an impartial way that does not exclude people, nor in technical way (physical access to technology) neither regarding their competences. Also, e-services demands that citizens have access and competence to use such services, creating a risk that digital excluded people might not get access to eservices and thus risks that the trust/legitimacy towards the government decreases. There is a need to meet and support those in need of additional support to be included [30] to keep up quality of government through trustworthy and legitimate relations.

Since public services in Sweden, as in most states, are provided by both national and local governmental agencies and authorities it is important to investigate interpretations of trust on different levels in the multilevel-government system as we have included in our survey [29]. However, when public services are provided in digital channels it might be more complex to see and understand the division of responsibility on national and local level in addition the private-public divisions of services and responsibilities. Trust towards national and local government agencies and politicians thus may vary [21].

\section{An inclusive research design}

The methodological ambition of this research project was to listen to the people living in the disadvantaged suburb and include their opinions on digital inclusion and quality of government into research. This in contrast to policy briefs and research talking about them.

To overcome the obstacles of a group hard to survey we worked in line with the approach used in disadvantaged suburb in Gothenburg. That research team lead by Esaiasson [5], searched for respondents by knocking on the door of respondents' homes and by walking in relevant areas of the suburb, for example the commercial center of the suburb, or being present at meetings for organizations. They focused on identity and trust through a short survey and provided an opening to participate in a full online survey.

\subsection{Our survey designs}

The design of our questionnaire had several points of departure, as it was part of a research project on sustainable digital government approaches in municipalities. Our research focus builds on the research overview on digital exclusion [31] and in particular van Dijks model [32] focusing on motivation, 
material access, competence, and use. Through our collaborative research approach the partnering public agencies also added some questions to the survey. In line with the study by Esaiasson's [5] in the suburb in Gothenburg we included questions on trust towards public sector and politicians. The underlying ambitions on digital inclusion is related to the idea of sustainable development as expressed in UN's Agenda 2030, thus the targets of the Global Sustainable Development Goals [33] have guided the design of the questions.

The main approach when formulating the questions was, however, to mirror the national survey "The Swedes and the Internet" [34] that has been running since 2000 and as a part of the World Internet Project [34] since 2010. "The Swedes and the Internet" is an annual web and phone survey managed by the independent Swedish Internet Foundation. In 2019, the survey contacted 17236 respondents and ended up with a response rate of $16 \%$. The survey focuses on issues like attitudes, access and use of technology, e-services, and the Internet. These results are used for policy formation and national strategies regarding digital inclusion and internet use. However, the low response rate indicates that the voices of weak groups with less competences and resources are not heard.

We formulated our questionnaire to mirror the "The Swedes and the Internet" and added questions to meet the specific groups in the disadvantaged suburb. The questionnaire included questions regarding background information about the respondent (age, language, sex, education etc.), attitudes, access and use of technology, e-services and the Internet, library visits, attitudes and experience of politics and democracy, trust towards public sector and politicians, we also asked parents (or care takers) regarding their children's internet usage. In total the questionnaire included 89 questions, a respondent could answer 83 questions at maximum. This due to that several questions conditioning other questions.

The questionnaire was made up in Swedish and translated into English, Arabic, Somalian, Bosnian/Croatian/Serbian, Persian, Dari and Sorani. There were some challenges with the translations and it happened that the interviewer had to discuss and explain the questions. The main challenge was to translate specific concept in the local community and the Swedish welfare system.

\subsection{Conducting the field study survey}

The field study survey was conducted during November 2019. We spent approximately six hours per day in the suburb to meet up with potential informants in the local shopping mall and some public meeting places, at meeting places for civil society organizations and by knocking on doors in the residential area. The team conducting the interviews consisted of five researchers and three students. All together the team making the interviews spoke eight languages fluently: Swedish, English, Arabic, Somalian, Bosnian/Croatian/Serbian, Persian, Dari and Sorani. By translating the questionnaire and having interview staff with competence in several languages, we got the impression that we drastically increased the response rate, as in line with Esiasson's [5] study in Gothenburg. There were respondents that said that they would not have participated if they had not been approached and if the questionnaire had not been in their language. During our field study a majority of the participants still used the Swedish version of the survey.

Studying diverse areas and groups is challenging when using ethnographic methods. The reason is because there are a lot of variables that could influence the results which makes it hard to demarcate. When studying ethnic diverse suburbs using ethnographic methods, as in our case, it is important not to explain the results slowly with ethnicity but relate to other to other socioeconomic factors, but also that there are more ethnic groups in play than only immigrants versus people born in the nation. The approach must also focus on the local context and the global context. It is true that ethnic diverse communities have an interesting local context but migrants living there have transnational and global relations that are not bound to the local context [35].

All respondents to the study were offered a voucher in a local grocery store worth 100 Swedish crowns (approximate 10 EURO). This encourage participation and was a compensation for the time (app. half an hour) spent to answer the questioner. The same approach was used in Gothenburg to raise the response rate [5]. Yet it is also becoming more common in research [36]. A risk of using vouchers is results becoming bias. An experience from our study is that some male youth tried to participate several times. However, this only occurred when recruiting participants in the shopping mall.

During the field study period, we kept a team journal noticing which area we covered each day, number of interviews, participating researchers and students, how many respondents who had accepted the cash check etcetera. We also made frequent field study notes on what happened and our impression of how the study progressed.

Our experiences of conducting the study was generally very positive, but time consuming. Most people were welcoming and opened if they were at home, in particular when they understood that we were not trying to sell them things and when we explained that there was no need to give any personal information. In few cases we also had to state that we did not have 
any contacts with the migration authorities. We were invited to several homes and it was not uncommon that we were offered drinks, sweets or cookies.

\subsection{Data analysis}

The analysis of our survey data was based on descriptive statistics of respondent characteristics and Pearson correlation analysis. Data for descriptive statistics was based on gender, age, educational level. employment status and ethno-cultural belonging. The correlation analysis was carried out for measures of internet use, trust in public agencies and experienced inclusion.

A Pearson's correlation coefficient was computed to assess the relationship between 'how often do you use internet' measured on a six points scale (from never to several times a day) with the following variables:

- $\quad$ 'ease of searching internet' measured on a five points scale from no not at all to completely agree.

- 'trustworthiness of information on internet' measured on a five-point scale from nothing to all.

- ' 'use of e-ID' measured on a five points scale from never to several times a day.

- ' 'use of on-line payment' measured on a five points scale from never to several times a day.

- 'Do you feel included in the society?' on a fivepoint scale from yes completely to no not at all.

- 'Do you feel included in the digital society?' on a five-point scale from yes completely to no not at all.

- ' trust in authorities' measured on a five-point scale from no, I don't agree at all to yes, I completely agree

- 'trust in local politicians' measured on five points scale from no, I don't agree at all to yes, I completely agree

- 'trust in national politicians' measured on a five-point scale from no, I don't agree at all to yes, I completely agree

\section{Welcome to Skäggetorp - The case study area}

This survey was conducted in a specific suburb called Skäggetorp, a residential area with a commercial center, a primary care center, schools, church and other places for civil society organizations.

\subsection{Living in Skäggetorp}

Skäggetorp is a suburb in Linköping municipality with approximately 10000 residents [37]. Of the total population $56 \%$ are born outside Sweden. The area has also lower income and lower education compared to other areas in Linköping [37] The area is one of the 60 vulnerable suburbs listed by the Swedish Police [24], due to influence of criminality. Still, several respondents described the suburb as good and as their home. In the high school in Skäggetorp 98\% of the students had a foreign background. Due to extremely low results for years the school will be closing, and students will be moved to schools outside the suburb [38]. This decision came after our field study but indicates the challenges in the suburb and our society.

When standing in the center of Skäggetorp the first thing you see is a big building built as a hotel in late 90s but that never opened. Instead the building has turned into a shopping mall including nationally common and more unique local stores. Skäggetorp is clearly visible on map because of a road encircling the area. Unlike other Swedish suburbs that often have unclear geographic boundaries [5]. The area mainly consists of rented apartments. During the fieldwork, one of the students commented "this road would be fixed in no time if this was the inner-city" while walking by a pit in the road.

Our survey results showed that Internet usage, e-ID usage and the own expression of being feeling included in digital society is lower than in Sweden in general. But also, that more than half of the respondents could imagine using the regional digital health center application of application. However, according to data from the regional authority [39] only two online consultancy meeting had been made in Skäggetorp in the range of 12 months. The statistics are from before Corona lock down, and after that there are indications of increased use of the app, in particular for testing of Convid-19. The analysis of e-health services [40], concludes and argues that public services need to be sustainable and more inclusive in a digital society. In relation to the arguments made here, the low take up of the e-health services indicates low impartial inclusion and risks of exclusion and low trust.

\subsection{What we have learned from field studies in Skäggetorp}

By working with this research design, we have learned to see digital inclusion in broader terms, and that it is vital for a sustainable society and good quality of government. By being present in the local community we have been invited to organizations, to base the study in relation to local conditions. By meetings with 
representatives from local authorities (libraries, city centers etc.) and civil society who fill the void as more and more services are digitalized and inhabitants do not comprehend them. At the same time, these organizations wish that more can be done.

We learned that cultural and linguistic competences to interact with respondent is positive in the process of conducting field work. But there is also a need for respondents to have competences and interest in contributing to the study as well. There were also cultural differences and for example to recruit Somali participants it was especially important to state that no personal information was collected. When rerouting non-internet users, it was beneficial to state that the survey included them too.

During the on-site interviews we also learned a lot more about the participants digital competences. For example, how they learned to use one single function on their smartphone, like a digital call application, but are not using any other digital apps, like bank-ID. This indicates that digital diversity is a relevant approach to understand the variety in digital competence and participation when it comes to communicating with authorities and using digital services.

\section{Findings}

\subsection{Respondents}

The final response rate of the survey was $65 \%$. A total of 500 people had an active contact and 323 responses were received in total. There were some incomplete responses using the response alternatives: "do not know" or "not willing to answer", these are still included here. Hence, a total of 323 responses were used for data analysis. Table 1 summarizes the demographic profile of the respondents.

Table 1. Demographic profile.

\begin{tabular}{|l|c|c|}
\hline & $\mathrm{N}$ & $\%$ \\
\hline Gender $(\mathrm{n}=320)$ & & 53 \\
\hline Men & 170 & 47 \\
\hline Women & 150 & \\
\hline Age $(\mathrm{n}=322)$ & & 28 \\
\hline $18-25$ & 90 & 39 \\
\hline $26-45$ & 125 & 19 \\
\hline $46-65$ & 60 & 14 \\
\hline $65+$ & 47 & \\
\hline Education $(\mathrm{n}=298)$ & & 38 \\
\hline Low & 114 & 49 \\
\hline Middle & 145 & 13 \\
\hline High & 39 & \\
\hline $\begin{array}{l}\text { Employment status } \\
\text { (n=323) }\end{array}$ & & \\
\hline
\end{tabular}

\begin{tabular}{|l|c|c|}
\hline Employed & 105 & 33 \\
\hline Unemployed & 40 & 12 \\
\hline Student & 78 & 24 \\
\hline Parental leave & 23 & 7 \\
\hline Sick leave & 16 & 5 \\
\hline Retired & 47 & 15 \\
\hline Other & 14 & 4 \\
\hline
\end{tabular}

$73 \%$ of the respondents were born outside Sweden, and $81 \%$ had at least one parent born outside Sweden. For the total Swedish population 19,6\% of the residents are born outside Sweden [41]

A key characteristic of disadvantaged suburbs in general [25] is the dominating of immigrants in addition to the confounding factor of unemployment. Thus, a key question in our survey was: "9. What is your ethnocultural/national background?". The interviewer here often had to add something like, what do you see as your personal ethnocultural belonging, it is up to you.

\section{Table 2. Ethno-cultural belonging}

\begin{tabular}{|l|c|c|}
\hline Origin $(\mathrm{n}=323)$ & $\mathrm{N}$ & $\mathbf{\%}$ \\
\hline Swedish & 75 & 23 \\
\hline Syrian & 34 & 11 \\
\hline Iraqi & 17 & 5 \\
\hline Syrian & 8 & 2 \\
\hline Somali & 104 & 32 \\
\hline Croatian & 1 & 0 \\
\hline Bosnian & 3 & 1 \\
\hline Serbian & 15 & 5 \\
\hline Iranian & 2 & 1 \\
\hline Afghan & 5 & 2 \\
\hline Kurdish & 7 & 2 \\
\hline Finnish & 2 & 1 \\
\hline Turkish & 0 & 0 \\
\hline Other or I don't know & 50 & 15 \\
\hline
\end{tabular}

Together this shows that we through the survey method reached a much more diffuse sample. There was a bias to younger respondents, as discussed in the method section. There is also a high representation of Somalis, that is slightly over their proportion in the suburb. In addition, the immigrants in Sweden with a background from Somalia are in general younger. So the bias regarding this group are might lower than what it might looks like.

\subsection{Correlation analysis of Internet use, trust and inclusion}

Table 3, on the next page, shows the results of the correlation analysis. 
Table 3. Correlation analysis of internet use, inclusion and trust

\begin{tabular}{|c|c|c|c|c|c|c|c|c|c|}
\hline & $\begin{array}{c}\text { INTERNET } \\
\text { USE }\end{array}$ & $\begin{array}{c}\text { EASE OF } \\
\text { USE }\end{array}$ & $\begin{array}{c}\text { TRUST- } \\
\text { WORTHY } \\
\text { INFORMATI } \\
\text { ON }\end{array}$ & $\begin{array}{l}\text { E-ID } \\
\text { USE }\end{array}$ & $\begin{array}{l}\text { ONLINE- } \\
\text { PAYMEN } \\
\text { T USE }\end{array}$ & $\begin{array}{c}\text { SOCIETY } \\
\text { INCLUSI } \\
\text { ON }\end{array}$ & $\begin{array}{l}\text { DIGITAL } \\
\text { SOCIETY } \\
\text { INCLUSI } \\
\text { ON }\end{array}$ & $\begin{array}{c}\text { TRUST IN } \\
\text { AUTHORI } \\
\text { TIES }\end{array}$ & $\begin{array}{l}\text { TRUST IN } \\
\text { LOCAL } \\
\text { POLITICI- } \\
\text { ANS }\end{array}$ \\
\hline EASE OF USE &, $194^{* *}$ & & & & & & & & \\
\hline $\begin{array}{l}\text { TRUSTWORTHY } \\
\text { INFORMATION }\end{array}$ & 0,125 &, $229^{* *}$ & & & & & & & \\
\hline E-ID USE &, $361^{* *}$ & 0,117 &, $149^{*}$ & & & & & & \\
\hline $\begin{array}{l}\text { ONLINE-PAYMENT } \\
\text { USE }\end{array}$ &, $373^{* *}$ &, $189^{* *}$ &, $225^{* *}$ &, $788^{* *}$ & & & & & \\
\hline $\begin{array}{l}\text { SOCIETY } \\
\text { INCLUSION }\end{array}$ &, $196^{* *}$ &, $192^{* *}$ &, $196^{* *}$ & 0,084 &, $146^{*}$ & & & & \\
\hline $\begin{array}{l}\text { DIGITAL SOCIETY } \\
\text { INCLUSION }\end{array}$ &, $337^{* *}$ &, $245^{* *}$ &, $317^{* *}$ &, $284^{* *}$ &, $253^{* *}$ &, $519^{* *}$ & & & \\
\hline $\begin{array}{c}\text { TRUST IN } \\
\text { AUTHORITIES }\end{array}$ &, $156^{*}$ &, $130^{*}$ & 0,072 & $0,01 \overline{4}$ & 0,034 &, $184^{* *}$ &, $266^{* *}$ & & \\
\hline $\begin{array}{l}\text { TRUST IN LOCAL } \\
\text { POLITICIANS }\end{array}$ &, $161^{*}$ &, $149^{*}$ &, $208^{* *}$ & 0,072 & 0,119 &, $327^{* *}$ &, $360^{* *}$ &, $527^{* *}$ & \\
\hline $\begin{array}{c}\text { TRUST IN } \\
\text { NATIONAL } \\
\text { POLITICANS }\end{array}$ & 0,114 &, $193^{* *}$ &, $243^{* *}$ & 0,093 &, $158^{*}$ &, $210^{* *}$ &, $289^{* *}$ &, $484^{* *}$ &, $674^{* *}$ \\
\hline
\end{tabular}




\section{Discussion}

Based on the correlation analysis, see table 3, we can overall conclude that in this sample from the specific disadvantaged suburb, respondents using the Internet experience that they are included in the digital society and thus feel included in the society in general. They also express higher trust in digital information, authorities and public agencies.

\subsection{Use of Internet and e-ID for Digital inclusion}

The results show that those using the Internet are expressing that they feel included in the digital society. However, it is even more clarifying that those who find it easy to use the Internet, are in this study also feeling included in the digital society. This indicates that confidence with using Internet correlates to a general idea of being included. However, it is not possible to say what comes first, Internet use or inclusion.

Another interesting result is that there is a correlation between Internet use and use of e-ID since it is used to access most public services online, as the learning platforms for schools, the social security agency, and municipal services. There is also a correlation showing that use of e-ID relates positively to experienced, self-reported, inclusion in the digital society. There is a strong correlation between e-ID use and online payments that demands e-ID. This is obvious, but it might open for a discussion on the importance of those using online payments to trust the e-ID system and thereby increase the feeling of inclusion in digital society.

\subsection{Inclusion and trust in politicians}

Based on the correlation analysis, see table 3, we can conclude that those who report feeling included in the digital society also feel included in the society in general and in addition they trust politicians and authorities. We can also see that those trusting either local or national politicians or authorities mostly also trust $<$ others as well. Which shows that digital inclusion seems to increase trust towards governmental institutions in general.

However, the trust towards local politicians is higher compared to national politicians. This is interesting since most of the public services in Sweden are organized and provided through local policy making processes. This can indicate that public service provision is important for the trust in politicians and the policy making processes, as suggested by the quality of government theory.
On the other hand, there was a stronger correlation between trust in national politicians and trustworthy information on the Internet, than between trust in local politicians and trustworthy information

This may indicate that those who have learned to be more critical to information on the Internet see national policymaking as more knowledge based and even professional. There is a need to further elaborate on the meanings behind these result and follow-up with interviews.

\section{Conclusions}

This paper shows that digital inclusion, in a disadvantaged suburb in Sweden, is related a higher feeling of inclusion in society and to trust in authorities and politicians.

We can hereby show that quality of government also should include dimensions of digital inclusion. We can show that there is a correlation between use of expressing a feeling of being included in the digital society and trust in politicians and public authorities. There is a need to elaborate more on how a digital society is governed in relation to trust and digital inclusion. This is in particular important regarding disadvantaged where Internet usage, e-ID use and inclusion in digital society is lower than in general. The digital exclusion adds another dimension to the discussion regarding if and why disadvantaged suburbs have a lower trust towards governmental institutions. Especially since digitalization of the public sector seems only to increase.

This paper also contributes by showing an innovative methodological approach to reach disadvantaged areas seen as hard to survey and make other voices heard in the discussions of quality of government. It is true that face-to-face surveys are not new but using and adapting it to suburbs in Sweden and getting a satisfactory response rate, is innovative. The research design from which this paper has emerged through a collaborative and intensive field study carries much more data to be included to nuance the implications and lessons learned. However, this approach can be recommended to deepen the understanding of digital inclusion, as asked for by van Dijk among others [1].

\section{Acknowledgement}

This study was made possible by the generous grant from the Swedish Research council FORMAS, grant number 2018-02366. This study could not have been completed without the team including colleagues in addition to the authors Dr Karin Skill and Dr Khalid 
Khayati, and the students Dirie Abukar, Samrad Garcis Goria and Neda Karami, but neither without the local organizations and residents in Skäggetorp.

\section{References}

[1] J. van Djik, The Digital Divide, Polity Press, Cambridge, 2020.

[2] E. Wihlborg. "Legitimate e-government: Public e-Services as a Facilitator of Political Legitimacy", Proceedings of the $47^{\text {th }}$ Annual Hawaii International Conference on System Science, IEEE, 2014, pp. 2148-2157.

[3] B. Rothstein, The quality of government: Corruption, social trust and inequality in international perspective, University of Chicago Press, 2011.

[4] R. D. Putnam. "E Pluuribus Unum: Diversity and Community in the Twenty-first Century The 2006 Johan Skytte Prize Lecture", Scandinavian Political Studies, 30, 2, 2007, pp. 137-174.

[5] P. Esaiasson, Förorten: Ett samhällvetenskapligt reportage, Timbro, Stockholm, 2019.

[6] Novus, Vad tycker människorna som bor i Sverige mest utsatta områden? En opinonsundersökning av Novus i Sveriges mest utsatta områden, 2018, Retrieved from https://novus.se/wpcontent/uploads/2018/12/481a2a45ad3da9f19a2f884b3a 99c71c.pdf

[7] L.A. Stoop, The hunt for the last respondent, SCP, The Hauge, 2005.

[8] M. Haan, Y.P. Ongena, K. Aarts. "Reaching Hard-toSurvey Populations: Mode Choice and Mode Preference", Journal of Official Statistics, 30, 2, 2014, pp. 355-379.

[9] A. van Deursen and J. van Djik. "The first-level digital divide shifts from inequalities in physical access to inequalities in material access", New Media \& Society, 21, 2, 2019, pp. 354-375.

[10] A. Gonzales. "The contemporary US digital divide: from initial access to technology maintenance", Information, Communication \& Society, 19, 2, 2016, pp. 234-248

[11] J. Humphry. "The importance of circumstance: Digital access and affordability for people experiencing homelessness", Australian Journal of Telecommunications and the Digital Economy, 2, 3, 2014, pp. 55.1-55.15.

[12] Z. Lin, L. Yang and Zhang. Z., "To include, or not to include, that is the question: Disability digital inclusion and exclusion in China", New Media \& Society, 2, 12, pp. 4436-4452.

[13] A. van Deursen, E. Helsper. "The Third-Level Digital divide: Who Benefits Most from Being Online?", Communications and Information Technologies Annual: Studies in Media Communication, 10, 2015, pp. 29-52.

[14] F.R.F Dos Santos and I.R Teixeira. "The efficacy of Digital Inclusion Educational Projects in Communities with High Social Vulnerability", World Journal of Education, 5, 3, 2006, pp. 131-138.

[15] R. Ramasamy. "Quality of government, public service delivery and institutional impartiality in etnically polarized societies: evidence for policy makers.", Asia
Pacific Journal of Public Administration, 42 (1), 2020, pp. 46-60.

[16] PewResearch 2015, Retrieved from https://www.pewresearch.org/internet/2015/06/26/ameri cans-internet-access-20002015/?fbclid=IwAR2iNR39eYCUuMZuA0bS6cSiXIXI yP5dvySPzU7nZZJawBw6TY5FaiBDE0o

[17] M. Nishijima, T.M Ivanauskas, M.F. Sarti. "Evolution and determints of digital divide in Brazil (2005-2013)", Telecommunications Policy, 41, 1, 2017, pp. 12-24.

[18] K. Kaufmann. "Navigating a new life: Syrian refugees and their Smartphones in Vienna", Information, Communication \& Society, 21, 6, 2018, pp. 882-898.

[19] S. Farshbaf. "A study of Transnational communication among Iranian Migrant Women in Australia”, Journal of Immigrant and Refugee Studies, 16, 3, 2018, pp. 293-312

[20] I. Bernhard et. al. "A Digital Society for All?: Meanings, Practices and Policies for Digital Diversity", Proocedings of the 52nd Hawaii International Conference on System Sciences, 2019, pp. 3067-3076.

[21] B. Rothstein, M. Samanni and J. Teorell. "Explaining the welfare state: power resources vs. the Quality of Government", European Political Science Review, 4 (1), 2012, pp. 1-28.

[22] B. Rothstein and E.M. Uslaner. "All for All: Equality, Corruption, and Social Trust", World Politics, 58, 1, 2005, pp. 41-72.

[23] B. Rothstein and J. Teorell. "What is Quality of Government? A Theory of Impartial Government Institutions. Governance: An International Journal of Policy, 21, 2, 2008, pp. 165-190.

[24] Swedish Police, Kriminell påverkan i lokalsamhället - En lägesbild för utvecklingen $\mathrm{i}$ utsatta områden, ref A309.000/2018, 2019.

[25] I. Molina. "Rasifiering - Ett teoretiskt perspektiv i analysen av diskriminering i Sverige", Bortom Vi och Dom Teoretiska reflektioner om makt, integration och strukturell diskriminering (red.) de los Reyes. P., Kamali. M., SOU 2005:41, pp. 95-112.

[26] M. Dahlstedt, (ed.), Förortsdrömmar, ungdomar, utanförskap och viljan till inkludering, Linköpings University, Linköping, 2018.

[27] J. Nieuwenhuis., et.al., "Does segregation reduce sociospatial mobility? Evidence from four European countries with different inequality and segregation context", Urban Studies, 57, 1, 2020, pp. 176-197.

[28] M. Berg and T. Johansson. "Trust and Safety in the Segregated City: Contextualizing the Relationship between Institutional Trust, Crime-related Insecurity and Generalized Trust", Scandinavian Political Studies, 39, 4, 2016, pp. 458-481.

[29] A. Olausson and E. Wihlborg. "The legitimacy of political entrepreneurs in networks: lessons from local development projects in Swedish municipalities", Governance and political entrepreneurship in Europe, Karlsson, C., Silander, C., \& Silander, D. (Eds.). Edward Elgar publishing, 2018.

[30] I. Bernhard, M. Gustafsson, K. Hedström, J. Sefyrin and E. Wihlborg. "A Digital Society for all? Meanings, Practices and Policies for Digital Diversity" 52 nd Hawaii 
International Conference on System Sciences (HICSS52), Maui, 8-11, 2019, pp. 3067-3076.

[31] H. Iacobaeus, M. Francisco, C. Nordqvist, J. Sefyrin, K. Skill and E. Wihlborg. Digitalt utanförskap: En forskningsöversikt, LiU-Tryck, Linköping, 2019.

[32] J. A. G. M van Dijk. "Digital divide research, achievements and shortcomings", Poetics, 34 (4-5), 2006, pp. 221-235.

[33] UN, Sustainable Development Goals, Retrieved from https://sdgs.un.org/goals

[34] Internetstiftelsen, Svenskarna och internet 2019, 2019, Retrieved

from https://svenskarnaochinternet.se/rapporter/svenskarnaoch-internet-2019/

[35] M. L. Berg and N. Sigona. "Ethnography, diversity and urban space", Identities, 20(4), 2013, pp. 347-360.

[36] S. Halperin, and O. Heath. Political Research: Methods and Practical Skills, Oxford University Press, Oxford, 2017.

[37] Linköping municipality, Statistik om Linköping, Retrivied from https://www.linkoping.se/kommun-och- politik/fakta-om-

linkoping/statistik/?fbclid=IwAR1K6OIRFQy3fAcJzJq HwgxHL fANAfgRv8ioWcD9Gk3sQs2170T98ceKvY

[38] Larsson. C., Gelin., L, Skäggetorpsskolan högstadium stängs hösten 2021, 2020, Retrieved from https://www.svt.se/nyheter/lokalt/ost/skaggetorpsskolan s-hogstadium-stangs-hosten-2021

[39] Region Östergötland, Statistiksammanställning.: Primärvårdscentrum. Januari 2020, 2020

[40] K. Skill and A. Kaharevic. "eHealth in the Hood: Exploring Digital Participation in a Swedish Suburb" S. Hofmann et. al. (eds) Electronic Participation, ePart 2020, pp. 121-132.

[41] Statistic Sweden, Stora demografiska skillnader i Sverige, 2018, Retrivied from: https://www.scb.se/hittastatistik/statistik-efter-

amne/befolkning/befolkningsframskrivningar/demografi sk-analys/pong/statistiknyhet/demokratisk-analysskilda-varldar-det-demografiskt-delade-sverige 